\title{
Supplementation of branched-chain amino acids to a reduced-protein diet improves growth performance in piglets: involvement of increased feed intake and direct muscle growth-promoting effect
}

\author{
Liufeng Zheng ${ }^{1}$, Hongkui Wei ${ }^{1,2}$, Chuanshang Cheng ${ }^{1}$, Quanhang Xiang ${ }^{1}$, Jiaman Pang ${ }^{1}$ and Jian Peng ${ }^{1,2 *}$ \\ ${ }^{1}$ Department of Animal Nutrition and Feed Science, College of Animal Science and Technology, Huazhong Agricultural \\ University, Wuban 430070, People's Republic of China \\ ${ }^{2}$ The Cooperative Innovation Center for Sustainable Pig Production, Wuban 430070, People's Republic of China
}

(Submitted 28 August 2015 - Final revision received 28 December 2015 - Accepted 1 February 2016 - First published online 15 April 2016)

\section{Abstract}

The aim of this study was to investigate whether supplementing branched-chain amino acids (AA) (BCAA) along with a reduced-protein diet increases piglet growth, and whether elevated feed intake and muscle growth-promoting effect contribute to this improvement. In Expt 1, twenty-eight weanling piglets were randomly fed one of the following four diets: a positive control (PC) diet, a reduced-protein negative control (NC) diet, an NC diet supplemented with BCAA to the same levels as in the PC diet (test 1 (T1)) and an NC diet supplemented with a 2 -fold dose of BCAA in T1 diet (test 2 (T2)) for $28 \mathrm{~d}$. In Expt 2, twenty-one weanling piglets were randomly assigned to NC, T1 and pair-fed T1 (P) groups. NC and T1 diets were the same as in Expt 1, whereas piglets in the P group were individually pair-fed with the NC group. In Expt 1, the NC group had reduced piglet growth and feed intake compared with the PC group, which were restored in T1 and T2 groups, but no differences were detected between T1 and T2 groups. In Expt 2, T1 and P groups showed increases in growth and mass of some muscles compared with the NC group. Increased feed intake after BCAA supplementation was associated with increased mRNA expressions of agoutirelated peptide and co-express neuropeptide $\mathrm{Y}(\mathrm{NPY})$ and phosphorylation of mammalian target of rapamycin (mTOR) and ribosomal protein S6 kinase 1 (S6K1), as well as decreased mRNA expressions of melanocortin-4 receptor and cocaine- and amphetamine-regulated transcript and phosphorylation of eukaryotic initiation factor $2 \alpha$ in the hypothalamus. No differences were observed among PC, T1 and T2 groups except for higher NPY mRNA expression in the T2 group than in the PC group (Expt 1). Phosphorylation of mTOR and S6K1 in muscle was enhanced after BCAA supplementation, which was independent of change in feed intake (Expt 2). In conclusion, supplementing BCAA to reduced-protein diets increases feed intake and muscle mass, and contributes to better growth performance in piglets.

Key words: Branched-chain amino acids: Piglets: Growth performance: Feed intakes: Muscle mass

Post-weaning diarrhoea is a major problem in pig production ${ }^{(1,2)}$, which can cause considerable loss due to mortality or production of non-marketable pigs ${ }^{(3)}$. As an effective strategy to solve this problem, reducing dietary protein level has been found to reduce the incidence of diarrhoea and the severity of digestive problems in piglets ${ }^{(4-6)}$. Recent studies have shown that reducing dietary protein intake could improve gastrointestinal health and function after weaning ${ }^{(7,8)}$. However, impairment of piglet growth begins to occur when crude protein $(\mathrm{CP})$ content is reduced from the level recommended by the National Research Council (NRC) ${ }^{(9)}$ to $17 \%$, balanced with the first four limiting amino acids (AA) (lysine, methionine, threonine and tryptophan) ${ }^{(10-12)}$. Thus, identifying the next-limiting AA that can maintain the growth performance of piglets fed reduced-protein diets is of enormous nutritional importance.

Numerous studies have suggested that branched-chain AA (BCAA), particularly valine and isoleucine, are the next-limiting AA for growth of piglets, and supplementation with these AA makes it possible to maintain growth performance of piglets fed reduced-protein diets ${ }^{(10,12,13)}$. Moreover, it has been demonstrated that dietary deficiency of AA causes a rapid decline in animal feed intake, which is particularly the case for BCAA in pigs $^{(14-16)}$ and mice ${ }^{(17)}$. In pigs, the suppressive effect of valine deficiency on feed intake is aggravated by an excess supply of leucine due to the shared enzymes in their catabolic pathways, which thereby increases the catabolism of valine ${ }^{(18)}$. However,

Abbreviations: AA, amino acids; ADFI, average daily feed intake; ADG, average daily gain; BCAA, branched-chain AA; BW, body weight; CART, cocaine- and amphetamine-regulated transcript; $\mathrm{CP}$, crude protein; eIF2 $\alpha$, eukaryotic initiation factor $2 \alpha$; GAAC, general amino acids control; G:F, gain:feed intake; LD, longissimus dorsi; MC4R, melanocortin-4 receptor; mTOR, mammalian target of rapamycin; NC, reduced-protein negative control; NPY, co-express neuropeptide Y; P, pair-fed T1; PC, positive control; S6K1, ribosomal protein S6 kinase 1; T1, test 1; T2, test 2.

* Corresponding author: J. Peng, fax +86 2787281 378, email pengjian@mail.hzau.edu.cn 
when valine and isoleucine requirement is fulfilled in the diet, an excess supply of leucine does not affect feed intake any more $^{(19,20)}$, but can act as a signalling molecule to increase muscle protein synthesis and growth performance in piglets $^{(20-22)}$. In addition, as leucine is the most effective single AA in promoting muscle protein synthesis via stimulating mammalian target of rapamycin (mTOR) pathway activity, addition of leucine to a reduced-protein diet to regulate animal growth has been the focus of many previous studies ${ }^{(23,24)}$. Thus far, little has been reported regarding the enhancing effect of supplementation of all the three BCAA to reduced-protein diets on the growth performance of piglets.

Several AA have been known to act as signal molecules in regulating feed intake of rodents ${ }^{(25-27)}$. However, the molecular mechanisms by which AA regulate the feed intake of pigs remain unknown. Hypothalamic neurons that express appetiteregulatory neuropeptides are considered as critical regulators of feeding behaviour and body weight (BW). Agouti-related peptide (Agrp) and co-express neuropeptide Y (NPY) stimulate feed intake, whereas pro-opiomelanocortin (POMC), melanocortin-4 receptor (MC4R) and cocaine- and amphetamine-regulated transcript (CART) inhibit feed intake ${ }^{(28)}$. Recently, two evolutionarily conserved signal transduction pathways, general AA control (GAAC) pathway in anterior piriform cortex (APC) and hypothalamus and mTOR pathway in hypothalamus, have been shown contribute to the regulation of feed intake in response to dietary AA changes ${ }^{(25-27)}$.

Taken together, we hypothesised that supplementation of BCAA to reduced-protein diets might increase feed intake and skeletal muscle mass in piglets, and these improvements are associated with changes in activities of related AA signalling pathways. Therefore, the aim of this study was to evaluate the effect of dietary BCAA supplementation on growth performance, feed intake and muscle mass in piglets fed reduced-protein diets with a CP content of $17 \%$. All diets were fortified with lysine, methionine, threonine and tryptophan to satisfy the standardised ileal digestible (SID) AA requirement. We further elucidated the roles of hypothalamic GAAC and mTOR signalling pathways in feed intake regulation as well as the role of mTOR signalling pathway involved in the control of muscle protein synthesis after dietary supplementation with BCAA.

\section{Methods}

Two experiments were conducted, and Huazhong Agriculture University Animal Care and Use Committee reviewed and approved the protocols for each experiment.

\section{Animals and diets}

In Expt 1, twenty-eight Large White $\times$ Landrace barrows weaned at $26 \mathrm{~d}$ of age were individually housed in metabolism cages $(1.5 \times 0.75 \mathrm{~m})$ with ad libitum access to feed and water. The piglets continued to receive the same commercial starter diet they had received since weaning for a $7-d$ adaptation period. Piglets were assigned to one of four treatments in a completely randomised design based on BW and ancestry seven per group.
Between 8 and $12 \mathrm{~d}$ after weaning, the starter diet was gradually replaced by the experimental diets, so that from $13 \mathrm{~d}$ after weaning piglets were fed the experimental diets only. The experiment began $13 \mathrm{~d}$ after weaning (a mean initial BW of 8.45 (SD 0.62$) \mathrm{kg}$ ) and lasted for $28 \mathrm{~d}$. Room temperature was initially set at $28^{\circ} \mathrm{C}$ and progressively decreased by $1^{\circ} \mathrm{C} /$ week. Piglets were weighed individually at the beginning and at the end of each week after an overnight fast. Feed intake was determined daily. Feed samples were collected weekly and pooled at the end of the experimental period for chemical analysis.

Four experimental diets based on maize and soyabean meal were formulated to differ in CP and BCAA contents (Table 1). Piglets were assigned randomly into one of the four diets, including a positive control (PC) diet, a reduced-protein negative control (NC) diet, a test 1 (T1) diet and a test 2 (T2) diet with CP contents of $19 \cdot 5,16 \cdot 7,16 \cdot 7$ and $17 \cdot 2 \%$, respectively. The NC diet was formulated without considering SID valine, leucine or isoleucine concentrations, but was supplemented with $0.42 \% \mathrm{Ala}$ (isonitrogenous amount), and thus was deficient in valine and isoleucine compared with the recommendation by the $\mathrm{NRC}^{(29)}$. The $\mathrm{T} 1$ diet was supplemented with $0 \cdot 17 \%$ isoleucine, $0.24 \%$ leucine and $0.16 \%$ valine to provide SID AA equal to the levels in the PC diet. The T2 diet was supplemented with a 2 -fold dose of each BCAA in T1 diet. All diets were fortified with lysine, methionine, threonine and tryptophan to satisfy the SID AA requirement as recommended by the $\mathrm{NRC}^{(29)}$.

One piglet from the PC group and one from the NC group were excluded because of death due to acute respiratory disease during the period of gradual replacement of the starter diet. At the end of the experiment, six pigs were selected randomly from each group to be humanely euthanised by electrical stunning, coupled with exsanguination after $12 \mathrm{~h}$ of feed deprivation. The hypothalamus was extracted from the brain within 5-10 min, and subsequently the hypothalamus samples were rapidly removed, wrapped in foil and frozen in liquid $\mathrm{N}_{2}$ to be stored at $-80^{\circ} \mathrm{C}$ until analyses.

In Expt 2, twenty-one Large White $\times$ Landrace barrows weaned at $28 \mathrm{~d}$ of age were individually housed in metabolism cages $(1.5 \times 0.75 \mathrm{~m})$ with ad libitum access to water and were fed a commercial diet for a 3 -d adaptation period. Subsequently, the piglets were assigned randomly to one of the three groups in a completely randomised design based on BW and ancestry seven per group, including NC, T1 and pair-fed T1 (P) groups. Gradual replacement of the starter diet by the experimental diets lasted for $5 \mathrm{~d}$. The experiment began $9 \mathrm{~d}$ after weaning when the piglets obtained a mean initial BW of $9 \cdot 21$ $(\mathrm{sD} 0.70) \mathrm{kg}$, and were fed the experimental diets, which lasted for $28 \mathrm{~d}$. NC and T1 diets were the same as in Expt 1 (Table 1). Piglets in the $\mathrm{P}$ group fed diet T1 were individually pair-fed with the piglets in the NC group as described by Swamy et al. ${ }^{(30)}$. In brief, piglets in the NC group had free access to feed, whereas piglets in the $\mathrm{P}$ group were provided with the same amount of feed consumed by the NC group piglets on the previous day. Piglets were weighed individually at the beginning and at the end of the experiment, and the feed intake was determined daily. One piglet from the NC group was excluded because of sudden death due to unknown causes at the beginning of week 1 . At the end of the experiment, all pigs were humanely 
Table 1. Composition of the experimental diets (as-fed basis)

\begin{tabular}{|c|c|c|c|c|}
\hline \multirow[b]{2}{*}{ Items } & \multicolumn{4}{|c|}{ Treatments* } \\
\hline & $\mathrm{PC}$ & NC & T1 & $\mathrm{T} 2$ \\
\hline \multicolumn{5}{|l|}{ Ingredients (\%) } \\
\hline Maize $(7.4 \% \mathrm{CP})$ & 59.86 & 70.09 & 70.09 & 70.09 \\
\hline Soyabean meal $(42.2 \% \mathrm{CP})$ & 22.00 & $10 \cdot 70$ & $10 \cdot 40$ & 9.60 \\
\hline Whey powder ( $4.0 \% \mathrm{CP})$ & 5.00 & 5.00 & 5.00 & 5.00 \\
\hline Fishmeal $(62.2 \% \mathrm{CP})$ & 4.00 & 4.00 & 4.00 & 4.00 \\
\hline $\begin{array}{l}\text { Concentrated soyabean protein } \\
(64.0 \% \mathrm{CP})\end{array}$ & 5.00 & $5 \cdot 00$ & $5 \cdot 00$ & $5 \cdot 00$ \\
\hline Soyabean oil & 0.79 & 0.40 & 0.50 & 0.70 \\
\hline L-Lys. $\mathrm{HCl}$ & 0.22 & 0.48 & 0.48 & 0.50 \\
\hline DL-Met & 0.14 & 0.23 & 0.23 & 0.24 \\
\hline L-Thr & 0.08 & 0.22 & 0.23 & 0.24 \\
\hline L-Trp & 0.01 & 0.06 & 0.06 & 0.06 \\
\hline L-lle & - & - & 0.17 & 0.34 \\
\hline L-Leu & - & - & 0.24 & 0.48 \\
\hline L-Val & - & - & $0 \cdot 16$ & 0.32 \\
\hline L-Ala & - & 0.42 & - & - \\
\hline Dicalcium phosphate & 1.00 & 1.30 & 1.30 & 1.30 \\
\hline Limestone & 0.60 & 0.60 & 0.60 & 0.60 \\
\hline Salt & 0.30 & 0.30 & 0.30 & 0.30 \\
\hline Bentonite & - & 0.20 & 0.24 & 0.23 \\
\hline Premix $†$ & 1.00 & 1.00 & 1.00 & 1.00 \\
\hline \multicolumn{5}{|l|}{ Analysed composition (\%) } \\
\hline $\mathrm{CP}$ & 19.5 & $16 \cdot 7$ & $16 \cdot 7$ & $17 \cdot 2$ \\
\hline Diethyl ether extract & 8.94 & 8.48 & 8.95 & 8.94 \\
\hline Crude fibre & $2 \cdot 77$ & $2 \cdot 34$ & 2.54 & $2 \cdot 36$ \\
\hline Lys & 1.33 & 1.32 & 1.34 & 1.33 \\
\hline Met + Cys & 0.89 & 0.88 & 0.88 & 0.91 \\
\hline Thr & 0.90 & 0.87 & 0.92 & 0.90 \\
\hline Trp & 0.22 & 0.21 & 0.22 & 0.22 \\
\hline Ile & 0.81 & 0.60 & 0.81 & 0.91 \\
\hline Leu & 1.80 & 1.45 & 1.83 & 1.98 \\
\hline Val & 0.96 & 0.76 & 0.95 & 1.05 \\
\hline His & 0.93 & 0.74 & 0.77 & 0.73 \\
\hline Phe & 0.51 & 0.42 & 0.44 & 0.41 \\
\hline $\operatorname{Arg}$ & 1.32 & 1.02 & 1.02 & 0.94 \\
\hline \multicolumn{5}{|l|}{$\begin{array}{l}\text { Calculated SID AA concentration } \\
\text { and NE value }(\%) \ddagger\end{array}$} \\
\hline $\mathrm{NE}(\mathrm{MJ} / \mathrm{kg})$ & $10 \cdot 37$ & $10 \cdot 38$ & $10 \cdot 38$ & $10 \cdot 37$ \\
\hline Total Ca & 0.74 & 0.77 & 0.77 & 0.76 \\
\hline Available P & 0.38 & 0.41 & 0.41 & 0.41 \\
\hline SID Lys & 1.23 & 1.23 & 1.23 & 1.23 \\
\hline SID Met + Cys & 0.68 & 0.68 & 0.68 & 0.68 \\
\hline SID Thr & 0.73 & 0.73 & 0.73 & 0.73 \\
\hline SID Trp & 0.20 & 0.20 & $0 \cdot 20$ & 0.20 \\
\hline SID lle & 0.75 & 0.58 & 0.75 & 0.90 \\
\hline SID Leu & 1.56 & 1.32 & 1.56 & 1.77 \\
\hline SID Val & 0.84 & 0.68 & 0.84 & 0.98 \\
\hline \multicolumn{5}{|l|}{ SID AA ratio } \\
\hline (Met + Cys):Lys & 0.55 & 0.55 & 0.55 & 0.55 \\
\hline Thr:Lys & 0.59 & 0.59 & 0.59 & 0.59 \\
\hline Trp:Lys & 0.16 & $0 \cdot 16$ & $0 \cdot 16$ & $0 \cdot 16$ \\
\hline lle:Lys & 0.61 & 0.47 & 0.61 & 0.73 \\
\hline Leu:Lys & 1.27 & 1.07 & 1.27 & 1.44 \\
\hline Val:Lys & 0.68 & 0.55 & 0.68 & 0.80 \\
\hline
\end{tabular}

$\mathrm{PC}$, positive control; NC, reduced-protein negative control; $\mathrm{T} 1$, test 1 ; $\mathrm{T} 2$, test 2 ; $\mathrm{CP}$ crude protein; SID, standardised ileal digestible; AA, amino acids; NE, net energy; BCAA, branched-chain AA; V, vitamin.

* PC diet and NC diet without considering SID Val, Leu or Ile concentration; T1 diet was formulated by adding $0.17 \% \mathrm{lle}, 024 \%$ Leu and $0.16 \%$ Val to the NC diet to achieve the levels in the PC group. T2 diet was supplemented with a 2-fold dose of each BCAA in the T1 diet.

† Provided per $\mathrm{kg}$ of diet (as-fed basis): VA, $15000 \mathrm{IU}(4500 \mu \mathrm{g}) ; \mathrm{VD}_{3}, 1500 \mathrm{IU}$ $(37.5 \mu \mathrm{g})$; VE, $30 \mathrm{mg} ; \mathrm{VB}_{1}, 3.2 \mathrm{mg}$; VB $2,8 \mathrm{mg} ; \mathrm{VB}_{6}, 4 \mathrm{mg} ; \mathrm{VB}_{12}, 0.03 \mathrm{mg} ; \mathrm{VK}_{3}$ $3.2 \mathrm{mg}$; niacin, $34 \mathrm{mg}$; folate, $1.6 \mathrm{mg}$; pantothenic acid, $18 \mathrm{mg}$; biotin, $0.2 \mathrm{mg}$; choline chloride, $500 \mathrm{mg}$; Cu, $150 \mathrm{mg} ; \mathrm{Fe}, 120 \mathrm{mg}$; Mn, $45 \mathrm{mg} ; \mathrm{Zn}, 90 \mathrm{mg}$; I, $0.6 \mathrm{mg}$ Se, $0.3 \mathrm{mg}$; Co, $0.3 \mathrm{mg}$; chlortetracycline, $35 \mathrm{mg}$; tiamulin $12 \mathrm{mg}$.

$\ddagger$ Values for SID AA concentration and NE were calculated according to the Nationa Research Council ${ }^{(29)}$. slaughtered by electrical stunning, coupled with exsanguination after $12 \mathrm{~h}$ of feed deprivation. In all, twenty-three major skeletal muscles from the forequarter, midquarter and hindquarter of the left carcass side were separated entirely and weighed (Table 5). The longissimus dorsi (LD) muscle samples between the 10th and the last rib on the right carcass side were rapidly removed, wrapped in foil and frozen in liquid $\mathrm{N}_{2}$ to be stored at $-80^{\circ} \mathrm{C}$ until analyses.

\section{Chemical analyses}

All diets were analysed for DM, CP $(\mathrm{N} \times 6.25)$, diethyl ether extract and crude fibre according to Association of Official Analytical Chemists ${ }^{(31)}$ procedures. Dietary AA contents were determined by ion-exchange chromatography using an Automatic Amino Acid Analyzer (Hitachi L-8800 Amino Acid Analyzer; Hitachi), and tryptophan content was analysed with an Agilent 1200 HPLC (Agilent Technologies) system using a $\mathrm{C} 18(4.6 \times 150 \mathrm{~mm})$ column after alkaline hydrolysis at $110^{\circ} \mathrm{C}$ for $20 \mathrm{~h}$ as previously described ${ }^{(32)}$. Feed samples were hydrolysed in $6 \mathrm{~N}-\mathrm{HCl}$ at $110^{\circ} \mathrm{C}$ for $24 \mathrm{~h}$ under reflux, whereas sulphur AA content was measured after performic acid oxidation before acid hydrolysis.

\section{Quantitative PCR}

Tissue samples of the hypothalamus in Expt 1 were homogenised and total RNA (tRNA) was isolated and purified using TRIzol Reagent (100 mg tissue/ $1 \mathrm{ml}$ Trizol; Life Technologies) according to the specifications of the manufacturer. The integrity of RNA was checked by $1 \%$ agarose gel electrophoresis stained with $1 \mu \mathrm{g} / \mathrm{ml}$ of ethidium bromide. The RNA concentration and quality were determined using the Nanodrop 2000 spectrophotometer (NanoDrop Technologies). A sample of $2 \mu \mathrm{g}$ of tRNA was reverse transcribed to synthesise complementary DNA (cDNA) for real-time PCR after treatment with TURBO ${ }^{\mathrm{TM}}$ DNase ( $2 \mathrm{U} / \mu \mathrm{l}$; Life Technologies) for $50 \mathrm{~min}$ at $37^{\circ} \mathrm{C}$ to remove contaminating genomic DNA. The primers used for the real-time PCR detection of selected genes are listed in Table 2. Real-time quantitative PCR analyses were performed (CFX Connect ${ }^{\mathrm{TM}}$ Real-time PCR Detection System; Bio-Rad) with a total volume of $10 \mu \mathrm{l}$ containing $5 \mathrm{ng}$ of $\mathrm{CDNA}, 5 \mu \mathrm{l}$ iTaq $^{\mathrm{TM}}$ Universal SYBR Green Supermix (Bio-Rad) and $0.3 \mu \mathrm{l}$ of each of forward and reverse primers. The relative qualification of gene expression for each sample was adjusted with the control gene $\beta$-actin using the $2^{-\Delta \Delta C_{T}}$ method $^{(33)}$ and normalised to the PC group.

\section{Western blotting}

The hypothalamus samples were used to detect the levels of p-mTOR, mTOR, p-ribosomal protein S6 kinase 1 (S6K1), S6K1, p-eukaryotic initiation factor $2 \alpha$ (eIF $2 \alpha)$ and eIF $2 \alpha$ proteins. The skeletal muscle samples were used to detect the levels of p-mTOR, mTOR, p-S6K1 and S6K1 proteins.

The frozen tissues samples were powdered under liquid $\mathrm{N}_{2}$, and the powdered tissue $(100 \mathrm{mg})$ was dissolved in $1 \mathrm{ml}$ protein lysis buffer containing 50 mm-Tris- $\mathrm{HCl}(\mathrm{pH} 7 \cdot 4), 150 \mathrm{~mm}-\mathrm{NaCl}$, $1 \%$ Triton $\mathrm{X}-100,1 \%$ sodium deoxycholate, $0 \cdot 1 \%$ SDS and 
Table 2. Primers used for real-time PCR analysis

\begin{tabular}{|c|c|c|c|c|}
\hline Genes & Accession no. & Direction & Sequences (5'-3') & Size \\
\hline \multirow[t]{2}{*}{$A g R P$} & \multirow[t]{2}{*}{ NM_001011693 } & Forward & CGTCGCTGCGTAAGGCT & \multirow[t]{2}{*}{99} \\
\hline & & Reverse & GCAGAAGGCGTTGAAGAAA & \\
\hline \multirow[t]{2}{*}{$N P Y$} & \multirow[t]{2}{*}{ NM_001256367 } & Forward & CGTACCCCTCCAAGCCCGACAAC & \multirow[t]{2}{*}{176} \\
\hline & & Reverse & AACATTTTCCGTGCCTTCTCT & \\
\hline \multirow[t]{2}{*}{ POMC } & \multirow[t]{2}{*}{ NM_213858 } & Forward & TCCGAGAAGAGCCAGACG & \multirow[t]{2}{*}{126} \\
\hline & & Reverse & GGCTTTGGGGTCGGCTTC & \\
\hline \multirow[t]{2}{*}{$M C 4 R$} & \multirow[t]{2}{*}{ NM_214173 } & Forward & CCCAGAATCCATACTGTGT & \multirow[t]{2}{*}{130} \\
\hline & & Reverse & TCTTTGAAGGTTTTCCTCAG & \\
\hline \multirow[t]{2}{*}{$C A R T$} & \multirow[t]{2}{*}{ NM_001099925 } & Forward & CCGCCCTGCTGCTGCTGCTAC & \multirow[t]{2}{*}{200} \\
\hline & & Reverse & AGGGACTTGGCCATACTTCTTCTC & \\
\hline \multirow[t]{2}{*}{$\beta$-Actin } & \multirow[t]{2}{*}{ AY550069 } & Forward & CCAGGTCATCACCATCGG & \multirow[t]{2}{*}{158} \\
\hline & & Reverse & CCGTGTTGGCGTAGAGGT & \\
\hline
\end{tabular}

$A g R P$, agouti-related peptide; NPY, co-express neuropeptide Y; POMC, pro-opiomelanocortin; MC4R, melanocortin-4 receptor; $C A R T$, cocaine- and amphetamine-regulated transcript.

Table 3. Effect of supplementing branched-chain amino acids (BCAA) to reduced-protein diets on growth performance of piglets (Expt 1) (Mean values with their pooled standard errors, $n$ 6-7/group)

\begin{tabular}{lccccccc}
\hline & \multicolumn{7}{c}{ Treatments $^{*}$} \\
\cline { 2 - 5 } Items & PC & NC & T1 & T2 & SEM & $P$ \\
\hline Initial BW (kg) & 8.50 & 8.36 & 8.54 & 8.38 & 0.56 & 0.952 \\
Final BW (kg) & $20.31^{\mathrm{a}}$ & $17.37^{\mathrm{b}}$ & $21.11^{\mathrm{a}}$ & $21.05^{\mathrm{a}}$ & 1.45 & 0.005 \\
ADFI (g/d) & & & & & & \\
Week 1 & $559^{\mathrm{a}}$ & $375^{\mathrm{b}}$ & $519^{\mathrm{a}}$ & $493^{\mathrm{a}}$ & 52 & 0.001 \\
Week 2 & $592^{\mathrm{a}}$ & $406^{\mathrm{b}}$ & $545^{\mathrm{a}}$ & $574^{\mathrm{a}}$ & 63 & 0.002 \\
Week 3 & $725^{\mathrm{a}}$ & $618^{\mathrm{b}}$ & $727^{\mathrm{a}}$ & $753^{\mathrm{a}}$ & 56 & 0.015 \\
Week 4 & $979^{\mathrm{a}}$ & $835^{\mathrm{b}}$ & $1038^{\mathrm{a}}$ & $1063^{\mathrm{a}}$ & 93 & 0.009 \\
Overall & $714^{\mathrm{a}}$ & $558^{\mathrm{b}}$ & $707^{\mathrm{a}}$ & $721^{\mathrm{a}}$ & 60 & 0.003 \\
ADG (g/d) & & & & & & \\
Week 1 & $350^{\mathrm{a}}$ & $189^{\mathrm{b}}$ & $346^{\mathrm{a}}$ & $325^{\mathrm{a}}$ & 51 & 0.001 \\
Week 2 & $324^{\mathrm{a}}$ & $223^{\mathrm{b}}$ & $309^{\mathrm{a}}$ & $322^{\mathrm{a}}$ & 43 & 0.010 \\
Week 3 & $419^{\mathrm{a}, \mathrm{b}}$ & $368^{\mathrm{b}}$ & $465^{\mathrm{a}}$ & $464^{\mathrm{a}}$ & 46 & 0.019 \\
Week 4 & $543^{\mathrm{a}, \mathrm{b}}$ & $481^{\mathrm{b}}$ & $627^{\mathrm{a}}$ & $653^{\mathrm{a}}$ & 73 & 0.012 \\
Overall & $422^{\mathrm{a}}$ & $322^{\mathrm{b}}$ & $449^{\mathrm{a}}$ & $452^{\mathrm{a}}$ & 44 & 0.001 \\
G:F & & & & & & \\
Week 1 & $0.63^{\mathrm{a}}$ & $0.49^{\mathrm{b}}$ & $0.66^{\mathrm{a}}$ & $0.65^{\mathrm{a}}$ & 0.06 & 0.004 \\
Week 2 & 0.55 & 0.56 & 0.57 & 0.57 & 0.08 & 0.966 \\
Week 3 & 0.58 & 0.60 & 0.64 & 0.62 & 0.05 & 0.326 \\
Week 4 & 0.56 & 0.58 & 0.60 & 0.61 & 0.04 & 0.250 \\
Overall & $0.59^{\mathrm{a}, \mathrm{b}}$ & $0.58^{\mathrm{b}}$ & $0.63^{\mathrm{a}}$ & $0.63^{\mathrm{a}}$ & 0.03 & 0.046 \\
\hline
\end{tabular}

$\mathrm{PC}$, positive control; NC, reduced-protein negative control; $\mathrm{T} 1$, test 1 ; $\mathrm{T} 2$, test 2 ; BW, body weight; ADFI, average daily feed intake; ADG, average daily gain; G:F, gain:feed intake; SID, standardised ileal digestible.

${ }^{a, b}$ Mean values within a row with unlike superscript letters were significantly different $(P<0.05)$.

* PC diet and NC diet without considering SID Val, Leu or lle concentrations; T1 diet was formulated by adding $0.17 \% \mathrm{lle}, 0.24 \%$ Leu and $0.16 \%$ Val to the NC diet to achieve the levels in the PC group. T2 diet was supplemented with a 2-fold dose of each BCAA in the T1 diet.

1 mm-phenylmethylsulphonyl fluoride plus a $10 \mu \mathrm{l}$ phosphatase inhibitors mixture (P1260; Applygen Technologies Inc.). After centrifugation at $10000 \mathrm{~g}$ and $4^{\circ} \mathrm{C}$ for $15 \mathrm{~min}$, the protein concentration in the supernatant fluid was determined by bicinchoninic acid assay (Beyotime Biotechnology) according to the manufacturer's instructions. All the samples were adjusted to an equal protein concentration and then diluted with $5 \times$ loading buffer (1.25 ml of $1 \mathrm{M}$-Tris- $\mathrm{HCl}$ ( $\mathrm{pH} 6 \cdot 8$ ), $2.5 \mathrm{ml}$ glycerol, $0.5 \mathrm{~g}$ SDS, $0.25 \mathrm{ml} \beta$-mercaptoethanol, $25 \mathrm{mg}$ bromophenol blue and $1 \mathrm{ml}$ water to a final volume of $5 \mathrm{ml}$ ) to a final volume of $1 \mathrm{ml}$. The samples were boiled for $10 \mathrm{~min}$ and cooled on ice
Table 4. Effect of supplementing branched-chain amino acids (BCAA) to reduced-protein diets on growth performance of piglets fed ad libitum or at a similar level in the group without supplemental BCAA (Expt 2) (Mean values with their pooled standard errors, $n 6-7 /$ group)

\begin{tabular}{lccccr}
\hline & \multicolumn{5}{c}{ Treatments $^{*}$} \\
\cline { 2 - 5 } Items & $\mathrm{NC}$ & $\mathrm{T} 1$ & $\mathrm{P}$ & & \\
\hline
\end{tabular}

NC, reduced-protein negative control; $\mathrm{T} 1$, test 1 ; $\mathrm{P}$, pair-fed $\mathrm{T} 1$ group; BW, body weight; ADFI, average daily feed intake; ADG, average daily gain; $G: F$, gain:feed intake; SID, standardised ileal digestible.

$a, b, c$ Mean values within a row with unlike superscript letters were significantly different $(P<0.05)$.

* NC diet without considering SID Val, Leu or lle concentrations; T1=test 1 diet, which was formulated by adding $0.17 \% \mathrm{lle}, 0.24 \%$ Leu and $0.16 \%$ Val to the NC diet; P, pair-fed T1 group, in which piglets fed the T1 diet were provided with the same amount of feed consumed by the NC group piglets.

before being used for Western blot analysis. Aliquots of samples $(50 \mu \mathrm{g}$ protein) were separated by electrophoresis on a $10 \%$ (S6K1), $12 \%(\mathrm{eIF} 2 \alpha)$ or $8 \%$ (mTOR) SDS-PAGE, and electrotransferred to poly vinylidene fluoride membranes (Millipore). The membranes were blocked in $5 \%$ fat-free milk in Tris-buffered saline containing $0 \cdot 1 \%$ Tween-20 (TBST) for $3 \mathrm{~h}$ and then incubated with the following primary antibodies at $4^{\circ} \mathrm{C}$ overnight with gentle rocking: anti-S6K1 (1:1000; Santa Cruz Biotechnology), anti-p-S6K1 (1:500; Affinity Biosciences), antieIF2 $\alpha$ (1:500; Affinity Biosciences), anti-p-eIF2 $\alpha$ (1:1000; Cell Signaling Technology), anti-mTOR (1:1000; Cell Signaling Technology), anti-p-mTOR (1:1000; Cell Signaling Technology) and anti- $\beta$-actin (1:1000; Santa Cruz Biotechnology). After being washed three times with TBST, the membranes were incubated at room temperature for $3 \mathrm{~h}$ with horseradish peroxidase-linked secondary antibodies diluted 1:20000 in 1\% bovine serum albumin TBST. Finally, the membranes were washed three times with TBST and three times with TBS, followed by development using the SuperSignal West Pico Chemiluminescent Substrate according to the manufacturer's instructions (Pierce). Images were quantified using the Gel Logic Pro 2200 system (Carestream Molecular Imaging) and Image J software. 
Table 5. Effect of supplementing branched-chain amino acids (BCAA) to reduced-protein diets on the absolute skeletal muscle mass of piglets fed ad libitum or at a similar level in the group without supplemental BCAA (Expt 2)

(Mean values with their pooled standard errors, $n 6-7 /$ group)

\begin{tabular}{|c|c|c|c|c|c|}
\hline \multirow[b]{2}{*}{ Items } & \multicolumn{3}{|c|}{ Treatments* $^{*}$} & \multirow[b]{2}{*}{ SEM } & \multirow[b]{2}{*}{$P$} \\
\hline & NC & $\mathrm{T} 1$ & $P$ & & \\
\hline \multicolumn{6}{|c|}{ Muscle mass in the forequarter $(\mathrm{g})$} \\
\hline Trapezius & $24.7^{\mathrm{b}}$ & $36 \cdot 1^{\mathrm{a}}$ & $33.5^{\mathrm{a}}$ & 3.8 & 0.006 \\
\hline Supraspinatus & $117 \cdot 2^{\mathrm{b}}$ & $140 \cdot 4^{\mathrm{a}}$ & $131 \cdot 2^{\mathrm{a}}$ & 6.9 & 0.002 \\
\hline Infraspinatus & $47 \cdot 6$ & 51.4 & $51 \cdot 8$ & $7 \cdot 9$ & 0.784 \\
\hline Teres major & 27.9 & $32 \cdot 7$ & 30.01 & 3.0 & $0 \cdot 160$ \\
\hline Deltoids & $16 \cdot 1^{\mathrm{c}}$ & $22 \cdot 8^{\mathrm{a}}$ & $19 \cdot 7^{\mathrm{b}}$ & 1.7 & 0.001 \\
\hline Subscapularis & $28 \cdot 3^{b}$ & $38 \cdot 4^{a}$ & $30 \cdot 8^{b}$ & 3.4 & 0.005 \\
\hline Tricepsbrachii & $176 \cdot 3^{\mathrm{b}}$ & $218 \cdot 7^{\mathrm{a}}$ & $194 \cdot 3^{a, b}$ & $17 \cdot 0$ & 0.021 \\
\hline Tensor fasciae antebrachii & $11.9^{\mathrm{b}}$ & $16 \cdot 4^{\mathrm{a}}$ & $13 \cdot 3^{a, b}$ & $2 \cdot 2$ & 0.065 \\
\hline Biceps & $30 \cdot 6^{\mathrm{b}}$ & $37.7^{\mathrm{a}}$ & $32 \cdot 8^{\mathrm{b}}$ & $2 \cdot 8$ & 0.016 \\
\hline Brachii & $26 \cdot 4$ & $30 \cdot 4$ & $27 \cdot 7$ & $2 \cdot 6$ & $0 \cdot 187$ \\
\hline \multicolumn{6}{|c|}{ Muscle mass in the midquarter $(\mathrm{g})$} \\
\hline Latissimus dorsi & $113.4^{\mathrm{b}}$ & $150 \cdot 7^{\mathrm{a}}$ & $143 \cdot 9^{a}$ & $17 \cdot 4$ & 0.031 \\
\hline Pectoralis profundus & $134.4^{\mathrm{b}}$ & $166 \cdot 6^{\mathrm{a}}$ & $155 \cdot 7^{\mathrm{a}, \mathrm{b}}$ & $17 \cdot 8$ & 0.097 \\
\hline Longissimus dorsi & $478.5^{\mathrm{c}}$ & $679 \cdot 1^{\mathrm{a}}$ & $573 \cdot 6^{\mathrm{b}}$ & 43.5 & $<0.001$ \\
\hline Psoas major & $76 \cdot 6$ & $97 \cdot 6$ & $87 \cdot 1$ & $10 \cdot 7$ & 0.113 \\
\hline \multicolumn{6}{|c|}{ Muscle mass in the hindquarter $(\mathrm{g})$} \\
\hline Glutaeus superficialis & $160 \cdot 1$ & $180 \cdot 9$ & $168 \cdot 0$ & $16 \cdot 2$ & 0.298 \\
\hline Gluteus medius & 33.5 & $40 \cdot 7$ & 38.8 & 4.4 & 0.129 \\
\hline Biceps femoris & $290 \cdot 2^{\mathrm{b}}$ & $371 \cdot 1^{\mathrm{a}}$ & $328 \cdot 3^{a, b}$ & $26 \cdot 2$ & 0.009 \\
\hline Semitendinosus & $89 \cdot 1^{\mathrm{b}}$ & $109 \cdot 9^{\mathrm{a}}$ & $93.3^{\mathrm{b}}$ & 7.5 & 0.007 \\
\hline Semembranosus & 71.9 & $84 \cdot 1$ & $72 \cdot 5$ & $10 \cdot 9$ & 0.309 \\
\hline Tensor fascia latae & $44 \cdot 2$ & 53.8 & 46.5 & $6 \cdot 0$ & 0.153 \\
\hline Gracilis & 61.4 & 73.7 & 65.8 & 8.2 & 0.203 \\
\hline Adductor & $161 \cdot 1$ & 191.4 & $177 \cdot 8$ & 24.6 & 0.318 \\
\hline Quadriceps femoris & $243 \cdot 2^{b}$ & $296 \cdot 0^{\mathrm{a}}$ & $266 \cdot 8^{a, b}$ & $22 \cdot 7$ & 0.031 \\
\hline
\end{tabular}

NC, reduced-protein negative control; T1, test 1; P, pair-fed T1 group; SID, standardised ileal digestible.

a,b,c Mean values within a row with unlike superscript letters were significantly different $(P<0.05)$.

* NC diet without considering SID Val, Leu or lle concentration; T1 was formulated by adding $0.17 \%$ Ile, $0.24 \%$ Leu and $0.16 \%$ Val to NC diet; P-fed T1 group, in which piglets fed the $\mathrm{T} 1$ diet were provided with the same amount of feed consumed by the NC group piglets.

\section{Statistical analyses}

For all data analyses, the individual piglet was used as the experimental unit. The data were analysed by ANOVA according to a randomised complete block design using general linear model procedures. Significant ANOVA effects were further examined using Duncan's multiple range test. Simple linear and quadratic relationships between feed intake and hypothalamic appetite regulatory gene expressions were determined using regression procedures. All analyses were performed using SAS 8.0. Results are presented as means with their standard errors. Probabilities $<0.05$ were considered as significant.

\section{Results \\ Growth performance}

The growth performance of piglets in Expt 1 is presented in Table 3. Compared with the PC group, the NC group showed a decrease $(P<0.05)$ in final BW, average daily gain (ADG) during weeks $1-2$, overall ADG (d 0-28) and gain:feed intake (G:F) during week 1.
Table 6. Effect of supplementing branched-chain amino acids (BCAA) to reduced-protein diets on relative skeletal muscle mass of piglets fed ad libitum or at a similar level in the group without supplemental BCAA (Expt 2) (Mean values with their pooled standard errors, $n$ 6-7/group)

\begin{tabular}{|c|c|c|c|c|c|}
\hline \multirow[b]{2}{*}{ Items } & \multicolumn{3}{|c|}{ Treatments* } & \multirow[b]{2}{*}{ SEM } & \multirow[b]{2}{*}{$P$} \\
\hline & NC & $\mathrm{T} 1$ & $\mathrm{P}$ & & \\
\hline \multicolumn{6}{|c|}{ Relative muscle mass in the forequarter $(\%) \dagger$} \\
\hline Trapezius & $0.137^{\mathrm{b}}$ & $0.163^{a, b}$ & $0 \cdot 182^{a}$ & 0.018 & 0.029 \\
\hline Supraspinatus & 0.647 & 0.643 & 0.710 & 0.045 & 0.187 \\
\hline Infraspinatus & 0.263 & $0 \cdot 231$ & 0.281 & 0.036 & 0.262 \\
\hline Teres major & 0.153 & 0.148 & 0.162 & 0.012 & 0.351 \\
\hline Deltoids & $0.091^{b}$ & $0 \cdot 105^{a}$ & $0 \cdot 106^{a}$ & 0.007 & 0.033 \\
\hline Subscapularis & 0.156 & 0.176 & $0 \cdot 167$ & 0.019 & 0.428 \\
\hline Tricepsbrachii & 0.970 & 0.993 & 1.052 & 0.077 & 0.431 \\
\hline Tensor fasciae antebrachii & 0.066 & 0.074 & 0.072 & 0.010 & 0.563 \\
\hline Biceps & $0 \cdot 168$ & $0 \cdot 171$ & 0.178 & 0.011 & 0.533 \\
\hline Brachii & 0.145 & 0.137 & 0.150 & 0.010 & 0.294 \\
\hline \multicolumn{6}{|c|}{ Relative muscle mass in the midquarter $(\%) \dagger$} \\
\hline Latissimus dorsi & $0.620^{b}$ & $0.681^{a, b}$ & $0 \cdot 780^{a}$ & 0.076 & 0.043 \\
\hline Pectoralis profundus & $0.738^{\mathrm{b}}$ & $0.751^{a, b}$ & $0.837^{a}$ & 0.056 & 0.089 \\
\hline Longissimus dorsi & $2.652^{b}$ & $3.090^{\mathrm{a}}$ & $3 \cdot 102^{a}$ & 0.229 & 0.044 \\
\hline Psoas major & 0.419 & 0.441 & 0.472 & 0.043 & 0.372 \\
\hline \multicolumn{6}{|c|}{ Relative muscle mass in the hindquarter (\%)† } \\
\hline Glutaeus superficialis & 0.878 & 0.824 & 0.910 & 0.074 & 0.376 \\
\hline Gluteus medius & 0.185 & 0.184 & 0.210 & 0.020 & 0.227 \\
\hline Biceps femoris & $1.597^{b}$ & $1.683^{\mathrm{a}, \mathrm{b}}$ & $1 \cdot 775^{\mathrm{a}}$ & 0.104 & 0.115 \\
\hline Semitendinosus & 0.493 & 0.499 & 0.506 & 0.038 & 0.913 \\
\hline Semembranosus & 0.400 & 0.381 & 0.391 & 0.058 & 0.920 \\
\hline Tensor fascia latae & 0.242 & 0.242 & 0.251 & 0.023 & 0.857 \\
\hline Gracilis & 0.342 & 0.332 & 0.356 & 0.037 & 0.759 \\
\hline Adductor & 0.877 & 0.873 & 0.965 & 0.121 & 0.586 \\
\hline Quadriceps femoris & $1 \cdot 344$ & 1.342 & 1.447 & 0.107 & 0.413 \\
\hline
\end{tabular}

NC, reduced-protein negative control; $\mathrm{T} 1$, test 1 ; $\mathrm{P}$, pair-fed $\mathrm{T} 1$ group; SID, standardised ileal digestible.

a,b Mean values within a row with unlike superscript letters were significantly different $(P<0.05)$.

* NC diet without considering SID Val, Leu or lle concentrations; T1 was formulated by adding $0.17 \%$ Ile, $0.24 \%$ Leu and $0.16 \%$ Val to NC diet; P-fed T1 group, in which piglets fed $\mathrm{T} 1$ diet were provided with the same amount of feed consumed by NC group piglets.

† Relative muscle mass is expressed as a percentage of the body weight.

No differences in piglet growth were detected among PC, T1 and T2 groups, but final BW, ADG for all experimental periods, G:F during week 1 and overall G:F were higher $(P<0.05)$ in T1 and T2 groups compared with the NC group. Interestingly, average daily feed intake (ADFI) for all experimental periods was decreased $(P<0.05)$ in the NC group, whereas in $\mathrm{T} 1$ and $\mathrm{T} 2$ groups it was restored to the levels of the PC group. Thus, we conducted a pair-feeding experiment (Expt 2) to ensure similar feed intake among piglets between NC and $\mathrm{P}$ groups. In Expt 2, ADFI was higher $(P<0.05)$ in the T1 group than in the NC group, which is consistent with the results of Expt 1 . T1 and $\mathrm{P}$ groups had significantly higher $(P<0.05)$ ADG and G:F compared with the NC group (Table 4).

\section{Skeletal muscle mass}

In total, twenty-three major skeletal muscles of piglets in NC, T1 and $\mathrm{P}$ groups were separated entirely and weighed in Expt 2. The results showed that the absolute (Table 5) and relative (expressed as a percentage of the BW) (Table 6) weights of skeletal muscles in piglets were affected by the treatments. Compared with the NC group, the absolute weights of most 
muscles in the forequarter and midquarter were enhanced $(P<0.05)$ in the T1 group, except for infraspinatus, teres major, brachii and psoas major muscles. Moreover, the absolute weights of three muscles with large mass (biceps femoris, semitendinosus and quadriceps femoris muscles) in the hindquarter were also increased $(P<0.05)$ in the T1 group. When the piglets were provided with the same amount of feed, the $P$ group had increased $(P<0.05)$ weights of LD, trapezius, supraspinatus, deltoids and latissimus dorsi muscles compared with the NC group, particularly LD muscle.

The $\mathrm{P}$ group showed higher $(P<0.05)$ relative weights of trapezius, deltoids, latissimus dorsi, pectoralis profundus, LD and biceps femoris muscles compared with the NC group. The relative weights of these muscles in the T1 group were intermediate between those in the other two groups, but only two muscles (deltoids and LD) showed statistically different weights $(P<0.05)$ compared with the NC group. There were no differences in the relative weights of other muscles among all the three groups.

mRNA expressions of appetite regulatory genes in the hypothalamus

Agrp and NPY are classified as orexigenic genes, but POMC, $M C 4 R$ and CART are classified as anorexigenic genes. We detected the mRNA expressions of these appetite regulatory genes in the hypothalamus in Expt 1, and the results are shown in Fig. 1. Hypothalamic Agrp and $N P Y$ mRNA levels were higher $(P<0.05)$ in the T2 group compared with the NC group (Fig. 1(A)), whereas $M C 4 R$ mRNA level in the T2 group and CART mRNA level in the T1 group were lower $(P<0.05)$ compared with the NC group (Fig. 1(B)). However, POMC mRNA level showed no differences among the four groups. Interestingly, there were no differences in hypothalamic Agrp, NPY, MC4R and CART mRNA levels among T1, T2 and PC groups, except for the higher $(P<0.05)$ NPY mRNA level in the T2 group compared with the PC group. Further regression analysis showed that ADFI was positively $(P<0.05)$ associated with $N P Y$ mRNA levels ranging from 0.32 to 2.94 , whereas it was not affected by further increase in NPY mRNA levels (Fig. 2(a)). ADFI linearly

(A)

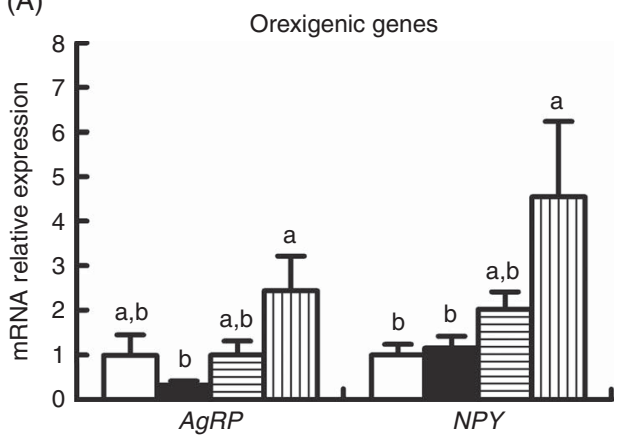

decreased $(P<0.05)$ with an increase in MC4R mRNA levels (Fig. 2(b)), whereas there were no significant quadratic or linear relationships between ADFI and the mRNA levels of Agrp and CART (data not shown).

Protein abundance of general amino acids control signalling pathway in the hypothalamus

Stimulation of the GAAC pathway in the hypothalamus has been shown to inhibit feed intake of animals. We detected the abundance of phosphorylated and total eIF $2 \alpha$ protein in the hypothalamus in Expt 1 by Western blotting. Compared with the PC group, the NC group had increased $(P<0.05)$ abundance of phosphorylated eIF $2 \alpha$ protein (expressed as a ratio to total eIF $2 \alpha$ or $\beta$-actin), which was restored to the that of the PC group in T1 and T2 groups (Fig. 3). The changes in the abundance of phosphorylated eIF $2 \alpha$ protein were opposite to the changes in feed intake. However, there was no difference in the abundance of total eIF $2 \alpha$ protein among the four groups.

\section{Protein abundance of mammalian target of rapamycin signalling pathway in the hypothalamus}

The protein abundance of mTOR signalling pathway in the hypothalamus in Expt 1 is shown in Fig. 4. The abundance of total S6K1 and mTOR proteins was not different among the four groups. However, compared with the NC group, PC, T1 and T2 groups had enhanced $(P<0.05)$ abundance of phosphorylated $\mathrm{S} 6 \mathrm{~K} 1$ protein (expressed as a ratio to total $\mathrm{S} 6 \mathrm{~K} 1$ or $\beta$-actin) (Fig. 4(A)). Moreover, the amount of phosphorylated mTOR protein (expressed as a ratio to total $\mathrm{mTOR}$ ) was higher in the T1 group $(P<0.05)$ than in the NC group (Fig. 4(B)). There were no differences in the abundance of phosphorylated S6K1 and mTOR proteins among PC, T1 and T2 groups.

\section{Protein abundance of mammalian target of rapamycin signalling pathway in longissimus dorsi muscle}

In Expt 2, compared with $\mathrm{T} 1$ and $\mathrm{P}$ groups, the $\mathrm{NC}$ group had reduced $(P<0.05)$ abundance of phosphorylated S6K1
(B)

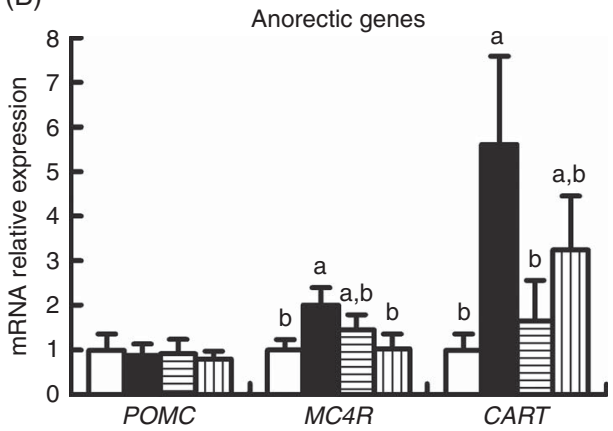

Fig. 1. mRNA levels of $(A)$ orexigenic genes (agouti-related peptide $(A g R P)$ and co-express neuropeptide $Y(N P Y))$ and $(B)$ anorectic genes (pro-opiomelanocortin $(P O M C)$, melanocortin-4 receptor $(M C 4 R)$ and cocaine- and amphetamine-regulated transcript $(C A R T))$ in the hypothalamus of piglets fed positive control (PC, $\square)$ diet, reduced-protein negative control (NC, $\square$ ) diet or two NC diets supplemented with a 1- or 2-fold dose of BCAA (test 1 (目) and test 2 (血), respectively) in Expt 1. Values were normalised using $\beta$-actin as an internal control. Data are expressed relative to expression in the PC group; values are means ( $n$ 4-6/group), with their standard errors represented by vertical bars. ${ }^{a, b}$ Mean values with unlike letters were significantly different $(P<0.05)$. 
(a)

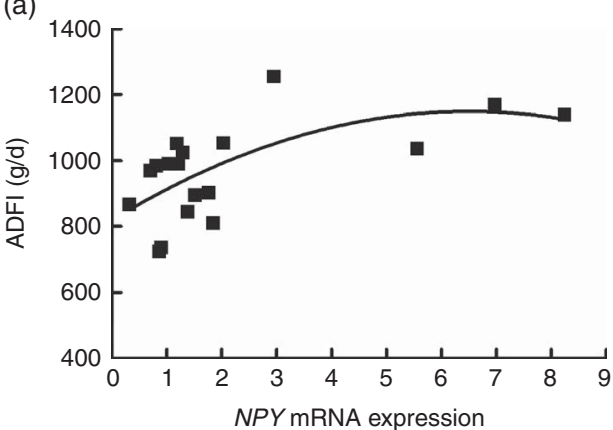

(b)

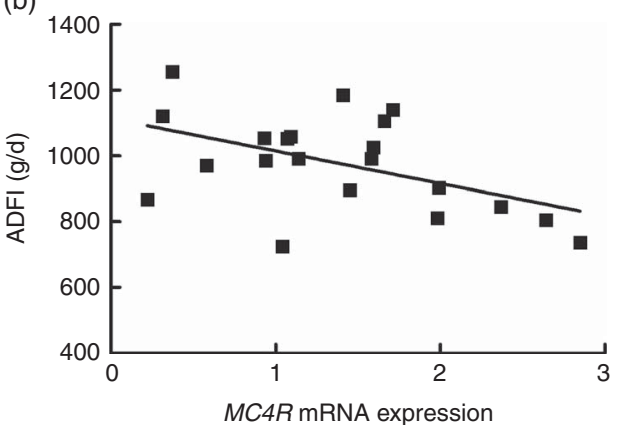

Fig. 2. Regression relationships between average daily feed intake (ADFI) in week 4 and the mRNA levels of (a) co-express neuropeptide $Y$ (NPY) $\left(y=-7.84 x^{2}+101.81 x+819.23 ; R^{2} 0.39 ; P=0.02\right)$ and (b) melanocortin-4 receptor $(M C 4 R)\left(y=-98.59 x+1113.68 ; R^{2} 0.24 ; P=0.02\right)$ genes in the hypothalamus of piglets.
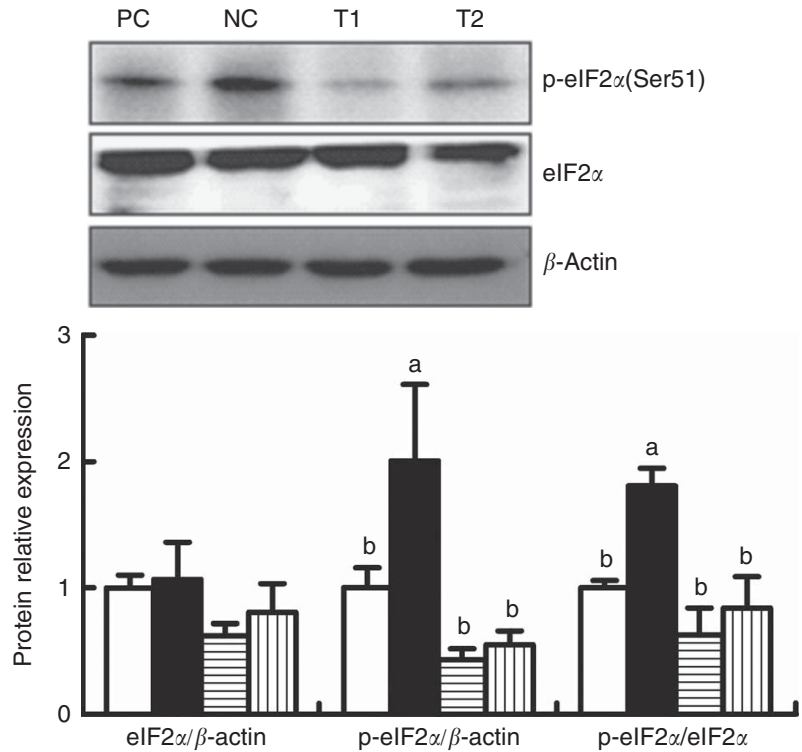

Fig. 3. Abundance of phosphorylated and total eukaryotic translation initiation factor $2 a$ (elF2a) protein in the hypothalamus of piglets fed positive control (PC, $\square$ ) diet, reduced-protein negative control (NC, $\square$ ) diet or two NC diets supplemented with a 1 - or 2-fold dose of BCAA (test 1 (目) and test 2 (目), respectively) in Expt 1. Western blotting method was used. Values were normalised using $\beta$-actin or relative total protein as an internal control. Data are expressed relative to expressions in the PC group; values are means ( $n$ 4-6/ group), with their standard errors represented by vertical bars. ${ }^{a, b}$ Mean values with unlike letters were significantly different $(P<0.05)$.

(Fig. 5(A)) and mTOR (Fig. 5(B)) proteins in LD muscle, whereas no differences were detected between $\mathrm{T} 1$ and $\mathrm{P}$ groups. Besides, the abundance of total S6K1 and mTOR proteins was not different among the three groups.

\section{Discussion}

The results of the present study showed that reducing $\mathrm{CP}$ content from 19.5 to $16.7 \%$ without balancing the BCAA levels impaired piglet growth, which was restored to the level of the PC group after supplementation with BCAA. However, the reduced-protein diet supplemented with a 2-fold dose of each BCAA did not further increase piglet growth. The positive effect of dietary BCAA supplementation on growth of piglets fed reduced-protein diets was also previously observed ${ }^{(11)}$. A novel and important finding of this study is that the increased feed intake of piglets is associated with the enhanced mTOR and reduced GAAC pathway activities in the hypothalamus after BCAA supplementation. Furthermore, we also indicate that BCAA may act as signalling molecules to increase local mTOR pathway activity, which is independent of change in feed intake, and thus might partly contribute to the elevated muscle mass after the supplementation of BCAA to the reducedprotein diet.

\section{Dietary branched-chain amino acids supplementation increases feed intake of piglets fed reduced-protein diets}

There are growing evidences showing that many species are able to sense a dietary AA imbalance and respond to it by reducing feed intake ${ }^{(26)}$. In growing pigs, the suppressive effect on growth after valine- or tryptophan-deficiency treatment is mainly associated with a reduction in feed intake ${ }^{(14-16,34)}$. Recent studies with mice have shown that dietary deficiency in isoleucine, valine and leucine causes the most dramatic decrease in feed intake ${ }^{(17)}$. In this study, we reported that the deficiency of valine and isoleucine in diet (NC group) for 4 weeks reduced the feed intake of piglets, which was restored to the level of the PC group after dietary supplementation with BCAA (Tables 3 and 4). In contrast, intracerebroventricular administration of leucine inhibited feed intake ${ }^{(25,35)}$. This paradoxical effect of leucine on feed intake is likely due to an extremely higher treatment level than the level under physiological conditions, which may lead to an imbalance among BCAA in the brain. Noteworthily, dietary BCAA imbalance (deficiency of valine and excess supply of leucine) results in subsequent reduction of feed intake in pigs ${ }^{(14-16,18)}$.

There have been a number of speculations about the mechanism responsible for the effect of dietary AA imbalance on the inhibition of feed intake in animals. In mice and rats, an AA imbalance is detected by the APC and the hypothalamus to inhibit feed intake ${ }^{(27,36,37)}$. AA deficiency stimulates the GAAC pathway via an accumulation of its uncharged tRNA, which induces phosphorylation of $\operatorname{eIF} 2 \alpha$ via the general control 
(A)
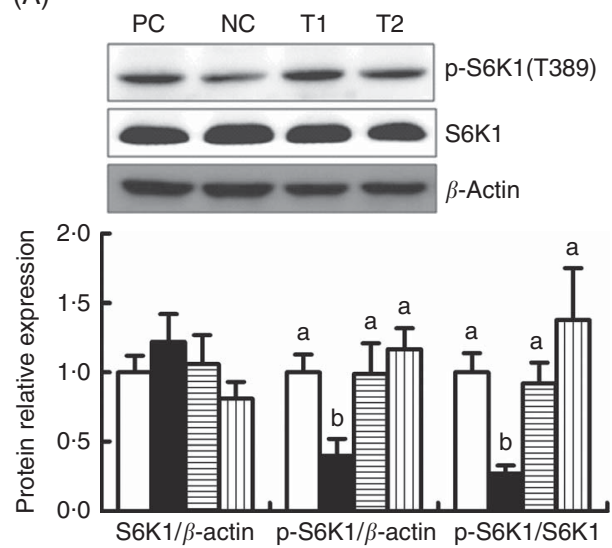

(B)
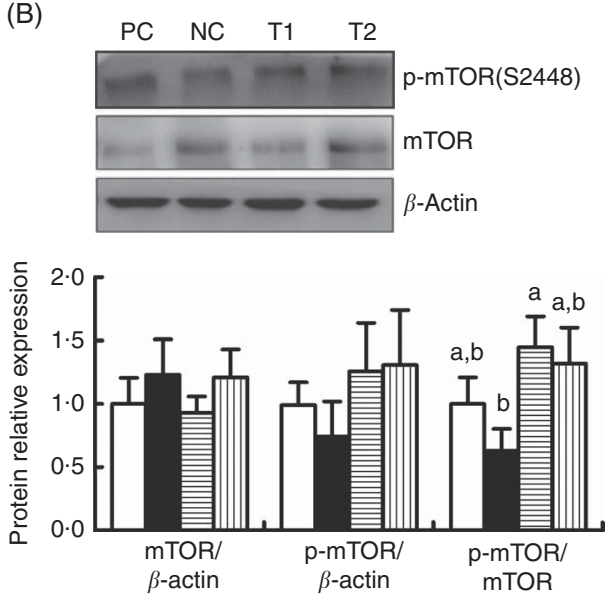

Fig. 4. Abundance of phosphorylated and total (A) ribosomal protein $\mathrm{S} 6$ kinase 1 (S6K1) and (B) mammalian target of rapamycin (mTOR) proteins in the hypothalamus of piglets fed positive control (PC, $\square$ ) diet, reduced-protein negative control (NC, $\square$ ) diet or two NC diets supplemented with a 1- or 2-fold dose of BCAA (test 1 (目) and test $2(\mathbb{U})$, respectively) in Expt 1. Western blotting method was used. Values were normalised using $\beta$-actin or relative total protein as an internal control. Data are expressed relative to expressions in the PC group; values are means ( $n 4-6 /$ group), with their standard errors represented by vertical bars. ${ }^{a, b}$ Mean values with unlike letters were significantly different $(P<0.05)$

(A)
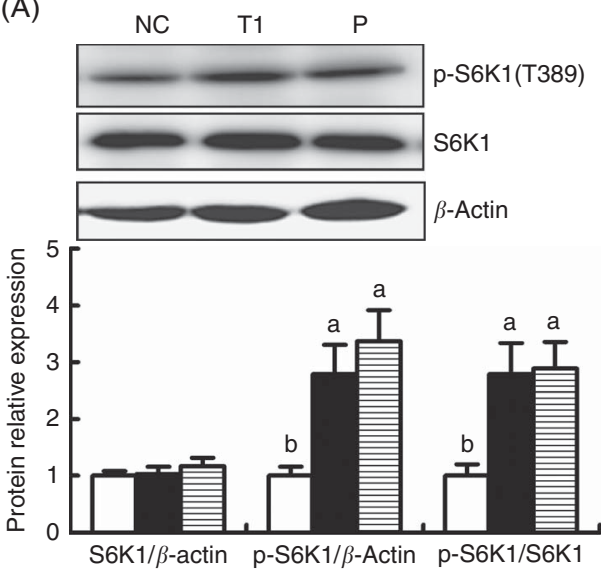

(B)
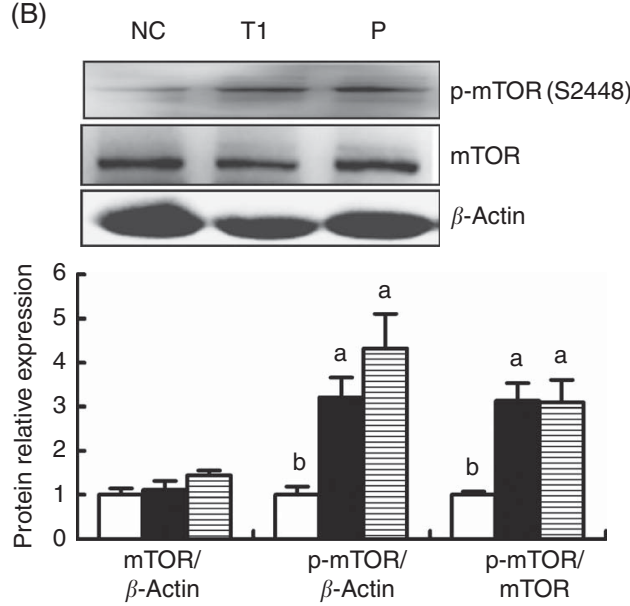

Fig. 5. Abundance of phosphorylated and total (A) ribosomal protein $\mathrm{S} 6$ kinase 1 (S6K1) and (B) mammalian target of rapamycin (mTOR) proteins in longissimus dorsi muscle of piglets in reduced-protein negative control (NC, $\square$ ) group, NC group supplemented with a 1-fold dose of BCAA (test 1 (T1, $\square$ ) or pair-fed T1 (P) (目) group in Expt 2. Piglets in $\mathrm{P}$ group were fed the same amount of T1 diet as the NC group piglets. Western blotting method was used. Values were normalised using $\beta$-actin or relative total protein as an internal control. Data are expressed relative to expressions in the NC group; values are means ( $n$ 4-6/group), with their standard errors represented by vertical bars. ${ }^{\text {a,b }}$ Mean values with unlike letters were significantly different $(P<0.05)$.

nonderepressible kinase 2 (GCN2). In addition, mTOR is a cellular fuel and AA sensor (leucine particularly), whose hypothalamic activity is directly related to the regulation of feed intake. A previous study showed that intracerebroventricular administration of leucine decreased the feed intake of rats by stimulating the mTOR pathway activity ${ }^{(25)}$. In contrast, central ghrelin administration promoted feed intake by stimulating hypothalamic mTOR pathway activity ${ }^{(38)}$. Further studies are needed to explain this seemingly paradoxical role of hypothalamic mTOR.

However, the roles of hypothalamic GAAC and mTOR signalling pathways, which are involved in the feed intake regulation by dietary AA, have not been identified in pigs. In our study, we reported for the first time that the increase in feed intake of piglets after dietary BCAA supplementation is related to the elevation/reduction of hypothalamic mTOR/GAAC pathway activity, which supports the speculation that the mTOR or GAAC pathway may play an important role in the positive effect of BCAA on the feed intake of piglets. Moreover, the expressions of hypothalamic appetite regulatory genes (Agrp and $N P Y$ ) that stimulate feed intake were up-regulated, but that of the genes inhibiting feed intake (MC4R and CART) were down-regulated after dietary BCAA supplementation (Fig. 1). Further assessment of the correlation between feed intake and expression of these appetite regulatory genes (Fig. 2) indicates that the expressions of $N P Y$ and $M C 4 R$ genes appear to be more responsive to BCAA supplementation compared with the other two genes. In addition, it has been demonstrated that hypothalamic mTOR plays an important role in regulating the expressions of appetite regulatory genes ${ }^{(25,38)}$. Morrison et $a l .{ }^{(39)}$ suggested that AA can act within the brain to inhibit 
feed intake of rats and that the direct mTOR-dependent inhibition of Agrp gene expression may contribute to this effect. These observations indicate that mTOR or GAAC may function as an AA sensor to regulate the expressions of hypothalamic appetite regulatory genes and feed intake in piglets. However, dietary supplementation with a 2 -fold dose of each BCAA in the present study did not further increase the feed intake of piglets (Table 3). As no changes in hypothalamic GAAC and mTOR pathway activities were observed between T1 and T2 groups (Fig. $3 \& 4$ ), it is possible that supplementing a 1-fold dose of BCAA to the reduced-protein diet is sufficient to activate these hypothalamic appetite regulatory signalling pathways.

\section{Dietary branched-chain amino acids supplementation increases muscle growth of piglets fed reduced-protein diets}

Skeletal muscle accounts for approximately $50 \%$ of the body mass. In the present study, the absolute weights of nearly half of the muscles (Table 5) and relative weights of some muscles (Table 6) were greater in both BCAA-supplemented T1 and $\mathrm{P}$ groups compared with the NC group. The increased muscle growth in response to BCAA supplementation may be due to, at least in part, the activation of translation initiation factors, which is supported by the stimulation of mTOR signalling pathway activity in LD muscle, independent of change in feed intake after dietary BCAA supplementation observed in the present study (Fig. 5). mTOR has been known to stimulate the activation of translation initiation factors induced by $\mathrm{AA}^{(40,41)}$. The effect of triggering the activation of translation initiation factors appears to be unique to BCAA, especially leucine, both in vivo ${ }^{(23,24)}$ and in intro ${ }^{(42,43)}$. It has been shown that supplementing excess leucine to reduced-protein diets increases the muscle protein synthesis of piglets by activating the mTOR signalling pathway to stimulate translation initiation ${ }^{(20-22)}$.

On the other hand, even though BCAA-supplemented T1 and $\mathrm{P}$ groups had similar muscular mTOR activity, the absolute weight of LD muscle in the $\mathrm{P}$ group did not reach the level of the T1 group (Table 5). Interestingly, a previous study has reported that protein synthesis in skeletal muscle was not stimulated by infusion of leucine for $2 \mathrm{~h}$ despite the continuous activation of translation initiation signals ${ }^{(23)}$. These results indicate that stimulation of muscle protein synthesis needs both the availability of sufficient substrates for synthesis and the activation of translation initiation factors.

In conclusion, the present study shows that supplementing BCAA to reduced-protein diets can increase growth performance of piglets, and the increase in feed intake and direct skeletal muscle growth-promoting effect contribute to this improvement. Our results for the first time indicate the possible important role of hypothalamic GAAC or mTOR pathway in the feed intake regulation of piglets after dietary BCAA supplementation. The muscle growth-promoting effect induced by BCAA supplementation may be mediated by the mTOR signalling pathway. However, supplementing a 2-fold dose of each BCAA to the reduced-protein diet in the present study did not further increase growth performance. Thus, further studies are needed to reveal the appropriate dose of each BCAA to be supplemented to the reduced-protein diet for maximum growth in piglets.

\section{Acknowledgements}

The authors are grateful for English revision from Z. Liu.

This study was jointly supported by the National Basic Research Programme of China (no. 2013CB127305), the Natural Science Foundation of Hubei Province of China (no. 2013CFA010) and the Fundamental Research Funds for the Central Universities (no. 2013PY047).

The authors' contributions are as follows: J. Peng, L. Z. and H. W. designed the research; L. Z., C. C., Q. X and J. Pang conducted the research; L. Z. analysed the data; L. Z., H. W. and J. Peng wrote the manuscript.

The authors have no conflicts of interest to declare.

\section{References}

1. McCracken BA, Gaskins HR, Ruwe-Kaiser PJ, et al. (1995) Diet-dependent and diet-independent metabolic responses underlie growth stasis of pigs at weaning. J Nutr $\mathbf{1 2 5}$, 2838-2845.

2. Brown DC, Maxwell CV, Erf GF, et al. (2006) The influence of different management systems and age on intestinal morphology, immune cell numbers and mucin production from goblet cells in post-weaning pigs. Vet Immunol Immunopathol 111, 187-198.

3. Rose N, Larour G, Le Diguerher G, et al. (2003) Risk factors for porcine post-weaning multisystemic wasting syndrome (PMWS) in 149 French farrow-to-finish herds. Prev Vet Med 61, 209-225.

4. Nyachoti CM, Omogbenigun FO, Rademacher M, et al. (2006) Performance responses and indicators of gastrointestinal health in early-weaned pigs fed low-protein amino acidsupplemented diets. J Anim Sci 84, 125-134.

5. Opapeju FO, Krause DO, Payne RL, et al. (2009) Effect of dietary protein level on growth performance, indicators of enteric health, and gastrointestinal microbial ecology of weaned pigs induced with postweaning colibacillosis. J Anim Sci 87, 2635-2643.

6. Kong X, Wu G, Liao Y, et al. (2007) Effects of Chinese herbal ultra-fine powder as a dietary additive on growth performance, serum metabolites and intestinal health in earlyweaned piglets. Livest Sci 108, 272-275.

7. Heo JM, Opapeju FO, Pluske JR, et al. (2013) Gastrointestinal health and function in weaned pigs: a review of feeding strategies to control post-weaning diarrhoea without using in-feed antimicrobial compounds. J Anim Physiol Anim Nutr (Berl) 97, 207-237.

8. Rist V, Weiss E, Eklund M, et al. (2013) Impact of dietary protein on microbiota composition and activity in the gastrointestinal tract of piglets in relation to gut health: a review. Animal 7, 1067-1078.

9. National Research Council (1998) Nutrient Requirements of Swine, 10th rev. ed. Washington, DC: The National Academies Press.

10. Lordelo M, Gaspar A, Le Bellego L, et al. (2008) Isoleucine and valine supplementation of a low-protein corn-wheat-soybean meal-based diet for piglets: growth performance and nitrogen balance. J Anim Sci 86, 2936-2941. 
11. Zhang S, Qiao S, Ren M, et al. (2013) Supplementation with branched-chain amino acids to a low-protein diet regulates intestinal expression of amino acid and peptide transporters in weanling pigs. Amino Acids 45, 1191-1205.

12. Le Bellego L \& Noblet J (2002) Performance and utilization of dietary energy and amino acids in piglets fed low protein diets. Livest Prod Sci 76, 45-58.

13. Nørgaard JV \& Fernández JA (2009) Isoleucine and valine supplementation of crude protein-reduced diets for pigs aged 5-8 weeks. Anim Feed Sci Tech 154, 248-253.

14. Gloaguen M, Le Floc'h N, Brossard L, et al. (2011) Response of piglets to the valine content in diet in combination with the supply of other branched-chain amino acids. Animal 5, 1734-1742.

15. Gloaguen M, Le Floc'h N, Corrent E, et al. (2012) Providing a diet deficient in valine but with excess leucine results in a rapid decrease in feed intake and modifies the postprandial plasma amino acid and alpha-keto acid concentrations in pigs. I Anim Sci 90, 3135-3142.

16. Gloaguen M, Le Floc'h N, Corrent E, et al. (2013) Meal patterns in relation to the supply of branched-chain amino acids in pigs. J Anim Sci 91, 292-297.

17. Kamata S, Yamamoto J, Kamijo K, et al. (2014) Dietary deprivation of each essential amino acid induces differential systemic adaptive responses in mice. Mol Nutr Food Res $\mathbf{5 8}$ 1309-1321.

18. Wiltafsky MK, Pfaffl MW \& Roth FX (2010) The effects of branched-chain amino acid interactions on growth performance, blood metabolites, enzyme kinetics and transcriptomics in weaned pigs. Br J Nutr 103, 964-976.

19. Soumeh EA, van Milgen J, Sloth NM, et al. (2015) The optimum ratio of standardized ileal digestible leucine to lysine for 8 to $12 \mathrm{~kg}$ female pigs. J Anim Sci 93, 2218-2224.

20. Yin Y, Yao K, Liu Z, et al. (2010) Supplementing L-leucine to a low-protein diet increases tissue protein synthesis in weanling pigs. Amino Acids 39, 1477-1486.

21. Murgas Torrazza R, Suryawan A, Gazzaneo MC, et al. (2010) Leucine supplementation of a low-protein meal increases skeletal muscle and visceral tissue protein synthesis in neonatal pigs by stimulating mTOR-dependent translation initiation. J Nutr 140, 2145-2152.

22. Suryawan A, Torrazza RM, Gazzaneo MC, et al. (2012) Enteral leucine supplementation increases protein synthesis in skeletal and cardiac muscles and visceral tissues of neonatal pigs through mTORC1-dependent pathways. Pediatr Res 71, 324-331.

23. Escobar J, Frank JW, Suryawan A, et al. (2005) Physiological rise in plasma leucine stimulates muscle protein synthesis in neonatal pigs by enhancing translation initiation factor activation. Am J Physiol Endocrinol Metab 288, E914-E921.

24. Escobar J, Frank JW, Suryawan A, et al. (2006) Regulation of cardiac and skeletal muscle protein synthesis by individual branched-chain amino acids in neonatal pigs. Am J Physiol Endocrinol Metab 290, E612-E621.

25. Cota D, Proulx K, Smith KAB, et al. (2006) Hypothalamic mTOR signaling regulates food intake. Science 312, 927-930.
26. Gietzen DW, Hao S \& Anthony TG (2007) Mechanisms of food intake repression in indispensable amino acid deficiency. Annu Rev Nutr 27, 63-78.

27. Maurin A-C, Benani A, Lorsignol A, et al. (2014) Hypothalamic eIF2 $\alpha$ signaling regulates food intake. Cell Rep 6, 438-444.

28. Morton G, Cummings D, Baskin D, et al. (2006) Central nervous system control of food intake and body weight. Nature 443, 289-295.

29. National Research Council (2012) Nutrient Requirements of Swine, 11th rev. ed. Washington, DC: The National Academies Press.

30. Swamy H, Smith T \& MacDonald E (2004) Effects of feeding blends of grains naturally contaminated with mycotoxins on brain regional neurochemistry of starter pigs and broiler chickens. J Anim Sci 82, 2131-2139.

31. Association of Official Analytical Chemists (2003) Official Methods of Analysis, 17th rev. ed. Arlington, VA: AOAC.

32. Wang X, Wei H, Cao J, et al. (2015) Metabolomics analysis of muscle from piglets fed low protein diets supplemented with branched chain amino acids using HPLC-high resolution MS. Electrophoresis 36, 2250-2258.

33. Livak KJ \& Schmittgen TD (2001) Analysis of relative gene expression data using real-time quantitative PCR and the $2^{-\Delta \Delta \mathrm{CT}}$ method. Methods 25, 402-408.

34. Ettle T \& Roth F (2004) Specific dietary selection for tryptophan by the piglet. J Anim Sci 82, 1115-1121.

35. Blouet C, Jo YH, Li X, et al. (2009) Mediobasal hypothalamic leucine sensing regulates food intake through activation of a hypothalamus-brainstem circuit. J Neurosci 29, 8302-8311

36. Maurin A-C, Jousse C, Averous J, et al. (2005) The GCN2 kinase biases feeding behavior to maintain amino acid homeostasis in omnivores. Cell Metab 1, 273-277.

37. Hao S, Sharp JW, Ross-Inta CM, et al. (2005) Uncharged tRNA and sensing of amino acid deficiency in mammalian piriform cortex. Science 307, 1776-1778.

38. Martins L, Fernández-Mallo D, Novelle MG, et al. (2012) Hypothalamic mTOR signaling mediates the orexigenic action of ghrelin. PLOS ONE 7, e46923.

39. Morrison CD, Xi X, White CL, et al. (2007) Amino acids inhibit Agrp gene expression via an mTOR-dependent mechanism. Am J Physiol Endocrinol Metab 293, E165-E171.

40. Meijer AJ \& Dubbelhuis PF (2004) Amino acid signalling and the integration of metabolism. Biochem Biophys Res Commun 313, 397-403.

41. Columbus DA, Fiorotto ML \& Davis TA (2015) Leucine is a major regulator of muscle protein synthesis in neonates. Amino Acids 47, 259-270.

42. Atherton PJ, Smith K, Etheridge T, et al. (2010) Distinct anabolic signalling responses to amino acids in $\mathrm{C} 2 \mathrm{C} 12$ skeletal muscle cells. Amino Acids 38, 1533-1539.

43. Hara K, Yonezawa K, Weng Q-P, et al. (1998) Amino acid sufficiency and mTOR regulate p70 S6 kinase and eIF-4E BP1 through a common effector mechanism. J Biol Chem 273, 14484-14494. 